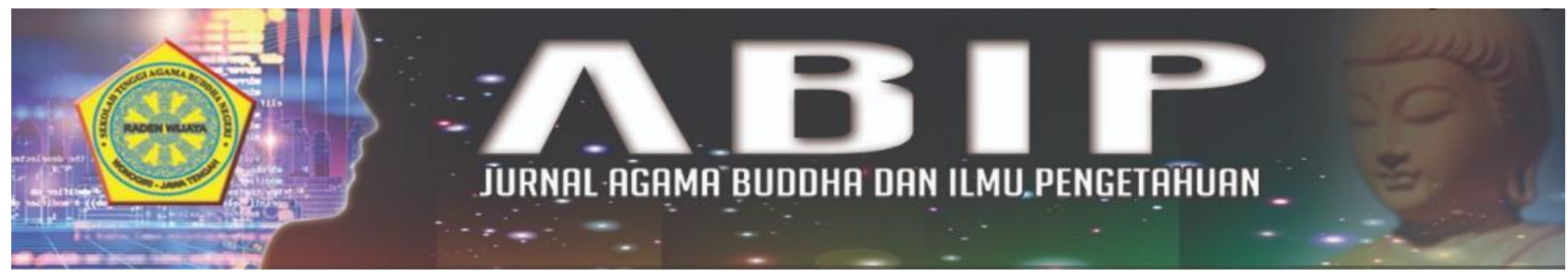

\title{
HUBUNGAN SIKAP SOSIAL SISWA DENGAN PRESTASI BELAJAR DI SD BINA BUDI MULIA MALANG
}

\author{
Mia Karnila \\ Sekolah Tinggi Agama Buddha Kertarajasa \\ Karnilamia@gmail.com
}

\begin{abstract}
Abstrak
Penelitian ini bertujuan untuk mengetahui tingkat sikap sosial siswa Sekolah Dasar Bina Budi Mulia Malang, mengetahui hubungan sikap sosial terhadap prestasi belajar siswa Sekolah Dasar Bina Budi Mulia Malang. Penelitian dilakukan dengan desain penelitian sensus, menggunakan metode deskriptif kuantitatif. Data yang diperoleh dari penyebaran angket dianalisis menggunakan skala likert dan koefisien korelasi pearson dengan uji-t dan data dokumen berupa nilai. Hasil penelitian menunjukkan adanya hubungan yang signifikan antara sikap sosial dan prestasi belajar. Dari hasil penelitian diperoleh nilai signifikan sikap tanggung jawab dengan persentase capaian $85 \%$, sikap jujur dengan persentase capaian $86 \%$, sikap disiplin dengan persentase capaian $85 \%$, sikap peduli dengan persentase capaian $64 \%$, sikap santun dengan persentase capaian $91 \%$ dan sikap percaya diri dengan persentase capaian $84 \%$. Nilai koefisien korelasi hubungan sikap sosial terhadap prestasi belajar sebesar 0,619 , sehingga dapat disimpulkan bahwa ada hubungan yang linier signifikan antara sikap sosial (X) dengan prestasi belajar (Y).
\end{abstract}

Kata Kunci: Sikap Sosial, Prestasi Belajar, siswa Sekolah Dasar

\begin{abstract}
This study aims to determine the level of social attitudes of students at Bina Budi Mulia Elementary School Malang, to determine the relationship of social attitudes to learning achievement of students at Bina Budi Mulia Elementary School Malang. The research was conducted with a census research design, using quantitative descriptive methods. The data obtained from the questionnaire distribution were analyzed using a Likert scale and Pearson correlation coefficient with $t$-test and document data in the form of values. The results showed a significant relationship between social attitudes and learning achievement. From the results of the study obtained a significant value of attitude of responsibility with percentage of achievement of $85 \%$, honest attitude with percentage of achievement of $86 \%$, disciplined attitude with percentage of achievement of $85 \%$, caring attitude with percentage of achievement of $64 \%$, polite attitude with percentage of achievement of $91 \%$ and self-confidence with a percentage of $84 \%$ achievement. The correlation coefficient value of the relationship between social attitudes and learning achievement is 0.619, so it can be concluded that there is a significant linear relationship between social attitudes $(X)$ and learning achievement $(Y)$.
\end{abstract}

Keywords: Social Attitude, Learning Achievement, Elementary School Students 


\section{PENDAHULUAN}

Sikap (attitude) adalah pandangan atau kecenderungan mental yang bereaksi dengan baik atau buruk terhadap orang atau barang tertentu (Syah, 2005:118). Pembelajaran kurikulum 2013 terdapat kompetensi inti yang dikembangkan dalam pembelajaran diantaranya kompetensi sikap spiritual, sikap sosial, pengetahuan dan keterampilan (Kemendikbud, 2016). Namun pada pelaksanaannya siswa belum bisa menunjukkan sikap sosial sesuai dengan indikator penilaian.

Pada awal penyebaran Covid-19 saat pembelajaran daring terdapat siswa yang tidak masuk tepat waktu, tidak berpakaian seragam sekolah, mematikan kamera pada saat pembelajaran, tidak menjawab saat guru memberi pertanyaan, tidak mengumpulkan tugas tepat waktu dengan alasan handphone masih dibawa Orangtua bekerja. Namun pada tahun 2021 sikap sosial siswa mulai ada peningkatan yang lebih baik. Oleh karena itu peneliti tertarik meneliti tentang hubungan sikap sosial siswa dengan prestasi belajar mata pelajaran agama Buddha di SD Bina Budi Mulia Malang tahun ajaran 2020/2021.

\section{TINJAUAN PUSTAKA}

\section{Sikap Sosial}

Sikap merupakan suatu hal yang menentukan sikap sifat, hakekat, baik perbuatan sekarang maupun yang akan datang (Ahmadi, 1999:162). sikap sosial dalam proses pembelajaran mencakup perilaku jujur, disiplin tanggung jawab, peduli, santun serta percaya diri (Kemendikbud, 2016). Menurut Ahmadi (2007:164-165) terdapat ciri-ciri sikap sosial yaitu, sikap itu dipelajari (learnability), memiliki kestabilan (stability), pemahaman sosial pribadi (personal-societal significance), berisi kognisi dan afeksi, pendekatan penghindaran terarah.

Fungsi sikap sosial menurut Ahmadi (2003:179) dapat dibagi menjadi empat golongan yakni, sikap berfungsi sebagai alat untuk menyesuaikan diri, sikap berfungsi sebagai alat pengatur tingkah laku, sikap berfungsi sebagai alat pengatur pengalaman- pengalaman, sikap berfungsi sebagai alat pernyataan pribadi. Faktor-faktor yang mempengaruhi sikap adalah pengalaman pribadi, kebudayaan, orang lain yang dianggap penting, media massa, lembaga pendidikan dan agama dan faktor emosi dalam diri.

\section{Prestasi Belajar}

Dalam proses pendidikan, kegiatan belajar merupakan kegiatan pokok guna mencapai tujuan pendidikan yang berupa prestasi belajar. Dalam kamus bahasa Indonesia kata prestasi memiliki pengertian hasil yang telah dicapai, pengertian tersebut sejalan dengan pendapat Poerwadarminta (dalam Djamarah, 1994:21), sedangkan menurut Nasrun Harahap (dalam Djamarah, 1994:21), membatasi pengertian prestasi sebagai penilaian tentang kemajuan dan perkembangan peserta didik mengenai penguasaan bahan pelajaran serta nilai yang terdapat dalam kurikulum.

Pada umumnya hasil belajar adalah perubahan tingkah laku dari segenap ranah, baik ranah kognitif, afektif dan psikomotorik yang merupakan indiktor hasil hasil pengalaman belajar siswa (Syah, 2005:15). Faktor-faktor yang mempengaruhi prestasi belajar menurut Slameto (2003:54-60) yaitu, faktor internal (dari dalam individu) dan faktor eksternal (dari luar individu).

\section{Mata Pelajaran Agama Buddha}

Mata pelajaran Agama Buddha merupakan pembelajaran yang di dalamnya berisikan suatu teori-teori pendidikan Agama Buddha. Selain menekankan pada pendidikan agama, pembelajaran Agama Buddha juga memberikan pendidikan budi pekerti, sehingga lebih dikenal dengan mata pelajaran pendidikan Agama Buddha dan budi pekerti. Pendidikan Agama Buddha dan budi pekerti adalah pendidikan yang memberikan pengetahuan dan membentuk sikap, pengetahuan, dan keterampilan peserta didik dalam mengamalkan ajaran agama Buddha, yang dilaksanakan sekurang-kurangnya melalui mata pelajaran pada semua jenjang pendidikan. 


\section{METODE PENELITIAN}

\section{Lokasi Penelitian}

Penelitian ini dilaksanakan di SD Bina Budi Mulia Malang dengan alamat Jl. Ade Irma Suryani 8, Kec Klojen, Malang, Jawa Timur. Penelitian ini difokuskan pada siswa SD Bina Budi Mulia Malang yang beragama Buddha sebagai subjek penelitian.

\section{Desain Penelitian}

Desain penelitian adalah keseluruhan proses yang diperlukan dalam perencanaan dan pelaksanaan penelitian, sehingga pertanyaan-pertanyaan yang ada dapat dijawab (Hasan, 2002:31). Desain penelitian yang digunakan dalam penelitian ini adalah sensus menggunakan metode deskriptif kuantitatif.

\section{Sumber Data}

Data primer (data utama) dan data sekunder (data pendukung).

\section{Variabel Penelitian}

Variabel bebas X (sikap sosial), dan Variabel terikat Y (prestasi belajar).

\section{Fokus Penelitian}

Fokus dari penelitian ini adalah untuk mengetahui hubungan sikap sosial siswa dengan prestasi belajar mata pelajaran agama buddha di SD Bina Budi Mulia Malang tahub ajaran 2020/2021.

\section{Populasi dan Sampel}

Populasi adalah wilayah generalisasi yang terdiri dari: objek/ subjek yang mempunyai kualitas dan karakteristik tertentu yang ditetapkan oleh peneliti untuk dipelajari dan kemudian ditarik kesimpulannya (Sugiyono, 2010: 177). Populasi dalam penelitian ini adalah siswa SD Bina Budi Mulia Malang yang beragama Buddha. Penelitian ini diambil dari populasi responden, dimana responden yang digunakan yaitu siswa SD Bina Budi Mulia Malang yang beragama Buddha terdiri atas kelas I (Satu) sampai kelas VI (Enam) berjumlah 20 orang.

\section{Instrumen Penelitian}

Pedoman angket, Dokumen dan pedoman wawancara

\section{Analisis Data}

Analisis data dengan skala likert dan analisis data dengan $u j i r$

\section{HASIL DAN PEMBAHASAN}

\section{A. Hasil}

1. Tingkat Sikap Sosial Siswa Sekolah Dasar Bina Budi Mulia Malang

Sikap sosial secara keseluruhan mempunyai skor total 2004 dengan kriteria sangat baik (SB) dengan persentase capaian $83 \%$ dari skor ideal yang diharapkan (100\%). Skor total keseluruhan yang tergolong sangat baik ini ternyata sangat didukung oleh skor parsial. Sedangkan secara parsial yang memiliki sikap tanggung jawab mempunyai skor 339 dengan persentase capaian $85 \%$, sikap jujur mempunyai skor 343 dengan persentase capaian 86\%, sikap disiplin mempunyai skor 339 dengan persentase capaian $85 \%$, sikap peduli mempunyai skor 255 dengan persentase capaian 64\%, sikap santun mempunyai skor 362 dengan persentase capaian $91 \%$, dan sikap percaya diri memiliki skor 334 dengan persen capaian 84\%. Dari 6 skor parsial 5 skor parsial tergolong sangat baik dan hanya 1 yang tergolong baik yaitu sikap sosial peduli. Perlu usaha bagaimana meningkatkan sikap sosial peduli dari baik (64\%) menjadi sangat baik. Kesimpulannya yaitu bagaimana mempertahankan prestasi yang sudah tergolong sangat baik tersebut.

\section{Hubungan Sikap Sosial dengan Prestasi Belajar}

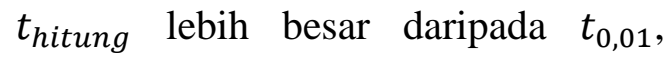
$t_{\text {hitung }} 4,262>t_{0,01}=2,861$, sehingga disimpulkan hubungan antara tingkat sikap sosial dengan prestasi belajar sangat nyata secara statistika. Semakin tinggi tingkat sikap sosial semakin tinggi pula prestasi belajarnya.

\section{B. Pembahasan}

\section{Tingkat Sikap Sosial Siswa SD Bina Budi Mulia Malang}

Berdasarkan hasil penelitian menunjukkan bahwa tingkat sikap sosial siswa SD Bina Budi Mulia Malang kelas I (Satu) sampai kelas VI (Enam) termasuk dalam kategori sangat baik (SB), yang dapat diartikan bahwa individu mampu bertanggung jawab, jujur, disiplin, 
santun serta percaya diri ditunjukkan dari hasil penghitungan yaitu kelas I (Satu) sampai kelas VI (Enam) dari 20 total siswa yang beragama Buddha. Hasil dari evaluasi total didukung dengan nilai hasil evaluasi parsial. Penilaian atau evaluasi secara parsial dari 6 indikator terdapat 30 kuesioner sikap sosial diperoleh nilai 1972 kemudian dengan persentase capaian 64,73\%. Namun, dari 6 indikator sikap sosial dan prestasi belajar yang telah dijawab, 1 indikator sikap peduli dalam kategori baik dengan skor 255 dengan persentase capaian 63,75\%. Dari 20 siswa $67 \%$ masuk dalam kategori sangat baik. Hal ini bisa terjadi karena sikap peduli siswa untuk menjenguk teman atau guru yang sedang sakit sangat rendah dan siswa lebih memilih untuk menunda-nunda untuk mengerjakan tugas.

Dengan demikian, dari hasil yang telah dijelaskan di atas maka dapat disimpulkan bahwa secara keseluruhan siswa kelas I (Satu) sampai kelas VI (Enam) memiliki sikap tanggung jawab, jujur, disiplin, santun serta percaya diri dan prestasi belajar dengan kategori sangat baik. Namun dari 30 pertanyaan kuesioner yang dijawab 27 pertanyaan dalam kategori sangat baik; 2 pertanyaan masuk dalam kategori tidak baik. Hal ini dikarenakan dalam membangun empati untuk sikap peduli kepada teman atau orang lain siswa cenderung tidak baik dan siswa lebih memilih menunda-nunda untuk mengerjakan tugas karena pembelajaran yang dilakukan sekarang online.

\section{Hubungan Sikap Sosial dengan Prestasi Belajar Mata Pelajaran Agama Buddha di SD Bina Budi Mulia Malang}

Berdasarkan perhitungan data hubungan antara sikap sosial terhadap prestasi belajar diketahui bahwa ada hubungan yang signifikan antara kedua variabel ini ditunjukkan dengan nilai koefisien korelasi yang kuat yaitu $r=$ 0,619 . Hal yang sama juga dijelaskan oleh Sugiyono (2010:19) bahwa jika $r$ besarnya $>0,600$ maka korelasi kuat. Maka ditentukan bahwa hubungan antara sikap sosial dan prestasi belajar tinggi atau ada hubungan.

Selain itu, semakin tinggi tingkat sikap sosial (X) maka nila siswa juga tinggi. Dari hasil penelitian tersebut terdapat beberapa faktor yang mempengaruhi yang diperoleh peneliti melalui kuesioner yang telah diisi oleh guru agama Buddha SD Bina Budi Mulia Malang kelas I (Satu) sampai kelas VI (Enam) yang menyatakan bahwa apabila siswa memiliki minat belajar, kemampuan kognitif, motivasi diri serta memiliki sikap (Afektif) yang baik maka siswa tersebut mampu mendapatkan nilai yang tinggi dan mampu meraih prestasi yang lebih baik. Bukan hanya itu, adanya hubungan antara sikap sosial dan prestasi belajar adalah nilai yang diperoleh dari penilaian tiga aspek meliputi: kognitif yang berorientasi pada kemampuan intelektual dari pemikiran siswa. Afektif yang berorientasi pada emosi, perasaan, sistem nilai dan sikap, dan psikomotorik berhubungan dengan keterampilan anggota badan yang memerlukan koordinasi syaraf dan otot yang didukung kemampuan mental serta perasaan.

Dalam kompetensi sosial terjadi peningkatan bahwa siswa lebih disiplin dalam masuk kelas dan mengumpulkan tugas. Hal tersebut terjadi karena disiplin berbasis nilai, siswa sudah mengetahui konsekuensi apa yang akan mereka dapatkan jika mereka terlambat untuk masuk kelas dan terlambat mengumpulkan tugas. Selain itu kelas menjadi semakin kondusif karena disiplin berbasis nilai dengan peraturan-peraturan yang telah ditetapkan. Kejujuran juga tercermin saat mengerjakan soal ulangan, siswa mengerjakan soal ulangan secara mandiri. Rasa aman yang diciptakan dalam kelas juga sangat mempengaruhi bagaimana siswa dengan percaya diri mengemukakan pendapatnya, hal tersebut terjadi karena siswa tidak takut untuk dipermalukann ketika salah dan tidak takut ditertawakan ketika salah.

\section{KESIMPULAN}

Berdasarkan analisis skala likert secara keseluruhan, dari evaluasi tingkat sikap sosial terhadap prestasi belajar siswa kelas I (Satu) sampai kelas VI (Enam) SD Bina Budi Mulia Malang termasuk dalam kategori sangat baik dengan skor total 2004 dan skor capaian $83, \%$ dari yang diharapkan $100 \%$. Hasil dari evaluasi total ini didukung oleh nilai hasil evaluasi parsial dimana dari enam sikap sosial, lima sikap sosial mempunyai kategori sangat 
baik dan hanya satu yang tergolong baik. Enam sikap sosial masing-masing mempunyai nilai sikap tanggung jawab memperoleh skor 339 dengan persentase capain $85 \%$, jujur memperoleh skor 343 dengan persentase capaian $86 \%$,disiplin memperoleh skor 339 dengan persentase capaian $85 \%$, peduli memperoleh skor 255 dengan persentase capaian 64\%, santun memperoleh skor 362 dengan persentase capaian $91 \%$ serta percaya diri memperoleh skor 334 dengan persentase capaian $84 \%$.

Nilai koefisien korelasi untuk menginterpretasi hubungan antara sikap sosial dan prestasi belajar mata pelajaran agama Buddha kelas I (Satu) sampai kelas VI (Enam) sebesar $r=0,619$, dengan tingkat signifikansi sangat nyata. Semakin tinggi tingkat sikap sosial, semakin tinggi pula prestasi belajar yang diperoleh. Siswa harus mempersiapkan diri dalam belajar dan berusaha untuk meningkatkan prestasi belajarnya agar dapat mendapatkan prestasi yang baik dan membanggakan.

\section{DAFTAR PUSTAKA}

1. Ahmadi, Abu. (1999). Psikologi Belajar. Jakarta: PT Rineka Cipta.

2. (2003). Ilmu Pendidikan. Jakarta: PT Rineka Cipta.

3. . (2007). Psikologi Belajar. Jakarta: PT Rineka Cipta.

4. Djamarah, Syaiful, B. (1994). Prestasi Belajar dan Kompetensi Guru. Surabaya: Usaha Nasional.

5. Hasan, Iqbal, (2002). Pokok-pokok Materi Metodologi Penelitian \& Aplikasinya. Bogor: Ghalia Indonesia.

6. Kementrian Pendidikan dan Kebudayaan. (2016). Materi Diklat Kurikulum 2013 Edisi Revisi Tahun 2016. Jakarta: Permendikbud.

7. Slameto. (2003). Belajar dan Faktorfaktor yang Mempengaruhinya. Jakarta: Rineka Cipta.

8. Sugiyono. (2010). Metode Penelitian Kuantitatif Kualitatif Dan $R \& D$. Bandung: Alfabeta.

9. Syah, Muhibidin. (2005). Psikologi Belajar. Jakarta: PT Raja Grafindo Persada. 